\title{
ポリマー構造から吸着速度を制御したポリカルボン酸系減水剂の効果 THE EFFECT OF POLYCARBOXYLATE-TYPE SUPERPLASTICIZER CONTROLLED ITS ADSORPTION RATE ONTO THE CEMENT PARTICLES BY CHANGING THE POLYMER STRUCTURE
}

\author{
枚田 健*, 名和豊 春** \\ Tsuyoshi HIRATA and Toyoharu NAWA
}

\begin{abstract}
Polycarboxylate-type superplasticizer (PC), which is controlled its adsorption rate on the cement particles by changing the polymer structure, is proposed. It was found that PC whose adsorption rate is slow shows the excellent slump retentive ability, on the other hand the faster adsorption rate gives the superior water reducing performance. Also we found the adsorption rate depends on the quantity of polycarboxylic acid groups, which are the adsorption groups on the cement particles, per PC molecule. And the last the PC adsorption conformation on the cement particles was discussed based on the hydrodynamic radius and computer simulation of PC.
\end{abstract}

Keywords: polycarboxylate, slump retention, water reducing, adsorption rate, hydrodynamic radius ポリカルボン酸, スランプ保持, 減水性, 吸着率, 流体力学的半径

\section{1.はじめに}

ポリカルボン酸系高性能 $\mathrm{AE}$ 減水剤は, 減水性能に優れることか ら，各種の高性能なコンクリートに応用されている11，2)。

著者らは, 減水性能とスランプ保持性能のそれぞれに特化した二 つのポリカルボン酸 (PC) を開発し, それらのブレンド比を適宜変 えて両性能を兼水備えた高性能 $\mathrm{AE}$ 減水剂を開発することを目的と して研究を進めてきた。本研究では, セメントへの吸着速度を制御 した PC のスランプ保持性能および減水性能が，吸着速度の遅速に 対応して変化することを見出し，その作用機構について検討した。 また, セメントペースト中での PC 分子のコンホメーションを, PC の固有粘度測定から求めた流体力学的半径および分子動力学的シミ ユレーションから推測される分子構造変化をもとに考察した。

\section{2. 使用したPCの化学構造}

$\mathrm{PC}$ には, 酸化エチレン（EO）付加モル数が $n$ モルのメトキシポ リ $(n)$ エチレングリコールメタクリル酸エステル（PGM- $n \mathrm{E} ）$ とメタ クリル酸（MAA）とのコポリマーのナトリウム塩を用いた。使用し た PCの構造式を図 1 に示寸。ここで, SMAA はメタクリル酸ナト リウムの略称である。

$\mathrm{PC}$ 中の MAA 鎖は, 水酸化ナトリウムで中和して, SMAA 鎖に変 換して用いた。用いた PCのモノマー組成比，側鎖の長さ $n, \mathrm{GPC}$

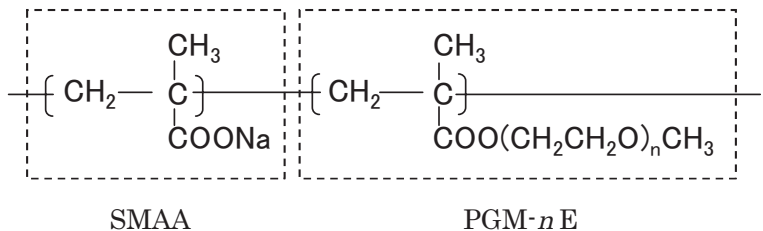

図 $1 \quad \mathrm{PC} の$ 構造式

法により求めた重量平均分子量 $\left(M w_{\mathrm{GPC}}\right)$ および $\mathrm{PC} 1$ 分子当たりの SMAA 数（mol）を表 1 に示す。ここで, モノマー組成比は, 重合 反応に用いた PGM- $n \mathrm{E}$ と SMAA の質量比率である。以下, ことわり のない限り, \%は質量\%, モルタルやコンクリートへの PC の添加量 は，セメント質量に対する固形分百分率（\%) で表す。

表 1 用いたPCの種類と性状

\begin{tabular}{|c|c|c|c|c|c|}
\hline No. & 名称 & $\begin{array}{c}\text { モノマー組成比 } \\
\text { PGM- } n \mathrm{E}^{\text {a) }} / \mathrm{SMAA}{ }^{\mathrm{b})}\end{array}$ & $\begin{array}{l}\text { 側鎖長 } n \\
\text { (モル) }\end{array}$ & $M W_{\mathrm{GPC}}{ }^{\mathrm{c})}$ & $\begin{array}{l}\text { PC1 分子当たりの } \\
\text { SMAA数 }(\mathrm{mol})\end{array}$ \\
\hline 1 & PC-10 & $75 / 25$ & 10 & 35,000 & 81 \\
\hline 2 & PC-25 (75/25) & $75 / 25$ & 25 & 22,000 & 51 \\
\hline 3 & $\mathrm{PC}-25(80 / 20)$ & $80 / 20$ & 25 & 23,000 & 43 \\
\hline 4 & PC-25 (85/15) -1 & $85 / 15$ & 25 & 19,000 & 26 \\
\hline 5 & PC-25 (85/15)-2 & $85 / 15$ & 25 & 47,000 & 65 \\
\hline 6 & PC-25 (85/15)-3 & $85 / 15$ & 25 & 77,000 & 107 \\
\hline 7 & PC-25 (87.5/12.5) & $87.5 / 12.5$ & 25 & 19,000 & 22 \\
\hline 8 & PC-25(91/9) & $91 / 9$ & 25 & 40,000 & 33 \\
\hline
\end{tabular}

* (株)日本触媒 上席研究員·工修 北海道大学大学院工学研究科環境循環システム専攻 博士後期課程

** 北海道大学大学院工学研究科環境循環システム専攻 教授・工博
Nippon Shokubai Fellow, Nippon Shokubai Co., Ltd., M. Eng. Graduate Student, Graduate School of Eng., Hokkaido University

Prof., Division of Solid Waste, Resources and Geoenvironmental Engineering, Hokkaido University, Dr. Eng. 


\section{PCのキャラクタリゼーション}

\section{(1) ゲル浸透クロマトグラフィー（GPC）}

GPCを用いてポリマーの $M w_{\mathrm{GPC}}$ を求めた。GPCは, 充填材にシリ カゲル系を用い, カラム温度は $40^{\circ} \mathrm{C}$ した。溶離液にはアセトニト リル $6,001 \mathrm{~g}$, 水 $10,999 \mathrm{~g}$, 酶酸ナトリウム三水和物 $115.6 \mathrm{~g}$ を混合し て酰酸でpH6.0に調整したものを用い, 流速 $1.0 \mathrm{~mL} / \mathrm{min}$.として, サン プル濃度は $0.5 \%$, サンプル注入量は $100 \mu \mathrm{L} と し$, 検出器にUV検出 器（波長 $220 \mathrm{~nm}$ ） と示差屈折計を用い, サンプルは $0.45 \mu \mathrm{m}$ のフィル ターでろ過し, 検量線作成標準物質にはポリエチレングリコールを 用いた。

\section{（2）セメントへの吸着率}

1） TOCによる測定（測定 1）:

$\mathrm{PC}$ が固形分で $15 \mathrm{mg}$ 溶解した水溶液 $100 \mathrm{~g}$ に, 普通ポルトランド セメント (OPC) $10 \mathrm{~g}$ を加えて摚挥し（添加量 $0.15 \%$ ), 所定時間経 過後にそれぞれ少量をサンプリングして $0.45 \mu \mathrm{m}$ のフィルターでろ 過し，全有機炭素濃度測定装置（TOC）を用いてセメントへの吸着 率を測定した。

また, PC-10 の吸着等温線を, 同様の方法で作成した。所定量の PC-10 の入った水溶液 $60 \mathrm{~g}$ と OPC $100 \mathrm{~g}$ をホモディスパーを用いて 1,200r.p.m.で 3 分間混練し, 10,000r.p.m.で遠心分離して $0.45 \mu \mathrm{m}$ の フィルターでろ過し，上澄み液を採取した。注水から要した時間は およそ 10 分であった。この上澄み液中の PC の濃度を TOC にて測 定し, セメントへの吸着量と水溶液中の $\mathrm{PC}$ 濃度を求め, 吸着等温 線を作成した。

\section{2） GPCによる測定（測定 2）：}

$\mathrm{PC}$ を固形分で $100 \mathrm{mg}$ 溶解した水溶液 $100 \mathrm{~g}$ に, ビーライトセメン 卜（Belite） $50 \mathrm{~g}$ を加えて擋拌し（添加量 $0.2 \%$ ), 所定時間経過毎に それぞれ少量をサンプリングして $0.45 \mu \mathrm{m}$ のフィルターでろ過した。 吸着率は, 万液中の $\mathrm{PC}$ の濃度を $\mathrm{GPC}$ の示差屈折計によるポリマー ピークの面積值から求め, その減少量から算出した。

また，セメントを $\mathrm{OPC}$ に変えて，PC を固形分で $120 \mathrm{mg}$ 或いは $200 \mathrm{mg}$ 溶解した水溶液 $100 \mathrm{~g}$ に, OPC $100 \mathrm{~g}$ を加えたセメントペース トで PC の吸着率を同様の方法で算出した（添加量 $0.12 \%, 0.2 \%$ ）。 表 2 に, 測定での試験条件を整理したものを示す。そして, OPC と Belite の化学成分と構成化合物を表 3 に示寸。

\section{(3) PC の吸着状態}

吸着したPCがセメント上でじのようなコンホメーションを取っ ているのかを知る手がかりとして, 光散乱法を用いて求めたPCの絶 対重量平均分子量 $\left(M w_{\mathrm{LS}}\right)$ と固有粘度から求められる流体力学的半 径 (hydrodynamic radius, $R_{h}$ ), および分子力場法と分子動力学法の二 つの方法で求めたポリマーの広がりを用いた。

\section{1）光散乱法}

装置は，VISCOTEK社製のGPC/SECシステムを用い，ポンプ，才 ートサンプラー, デガッサーから成る GPC送液システムViscotek GPCmax VE2001 GPC SOLVENT/ SAMPLE MODULEに, 示差屈折計, キャピラリー粘度検出器および光散乱検出器を備えたTDA302 TRIPLE DETECTOR ARRAYを接続して用いた。

溶離液には，水 $7,934.5 \mathrm{~g}, \mathrm{H}_{3} \mathrm{BO}_{3} 49.5 \mathrm{~g}, \mathrm{NaOH} 16.0 \mathrm{~g}$ 老混合した pH9.1の $100 \mathrm{mM}$ ホ酸ナトリウム緩衝液8,000gにアセトニトリル 2,000gを加えて用いた。カラムは東ソー株式会社製のTSK guard

\begin{tabular}{|c|c|c|c|c|}
\hline 測定 & $\begin{array}{c}\mathrm{PC} \text { 添加量 }{ }^{\mathrm{a})} \\
(\%) \\
\end{array}$ & $\begin{array}{c}\mathrm{W} / \mathrm{C} \\
\text { (質量比) }\end{array}$ & 測定方法 & セメントの種類 \\
\hline \multirow{2}{*}{1} & 0.15 & $100 / 10$ & \multirow{2}{*}{ TOC } & \multirow{2}{*}{$\mathrm{OPC}$} \\
\hline & $0.05 \sim 0.4$ & $60 / 100$ & & \\
\hline \multirow{2}{*}{2} & 0.2 & $100 / 50$ & \multirow{2}{*}{ GPC } & Belite \\
\hline & $0.12,0.2$ & $100 / 100$ & & $\mathrm{OPC}$ \\
\hline
\end{tabular}

a) セメントに対する固形分\%

表 3 セxントの化学成分と構成化合物

\begin{tabular}{|c|c|c|c|c|c|c|c|c|c|c|c|}
\hline \multirow{2}{*}{$\begin{array}{l}\text { セメント } \\
\text { の種類 }\end{array}$} & \multirow[t]{2}{*}{ 比重 } & \multirow{2}{*}{$\begin{array}{c}\text { 比表面積 } \\
\left(\mathrm{cm}^{2} / \mathrm{g}\right)\end{array}$} & \multicolumn{5}{|c|}{ 化学成分 (\%) } & \multicolumn{4}{|c|}{ 構成化合物 (\%) } \\
\hline & & & ig.loss & $\mathrm{MgO}$ & $\mathrm{SO}_{3}$ & $\mathrm{Na}_{2} \mathrm{O}$ & $\mathrm{Cl}^{-}$ & $\mathrm{C}_{3} \mathrm{~S}$ & $\mathrm{C}_{2} \mathrm{~S}$ & $\mathrm{C}_{3} \mathrm{~A}$ & $\mathrm{C}_{4} \mathrm{AF}$ \\
\hline $\mathrm{OPC}$ & 3.16 & 3,410 & 0.6 & 1.6 & 2.0 & 0.4 & 0.004 & 53 & 20 & 8 & 9 \\
\hline Belite & 3.20 & 4,210 & 0.6 & 0.8 & 2.6 & 0.2 & 0.004 & 33 & 49 & 4 & 9 \\
\hline
\end{tabular}

column $\alpha$ に, TSKgelシリーズの $\alpha-5000, \quad \alpha-4000, \quad \alpha-3000$ なな いで用い, カラム温度 $40^{\circ} \mathrm{C}$, 流速 $0.8 \mathrm{~mL} / \mathrm{min}$. とした。サンプル濃度 は1.0 vol.\%, サンプル注入量 $250 \mu \mathrm{L}$ と, サンプルは0.45 $\mu \mathrm{m}$ のフ イルターでろ過した。

\section{2) 分子力場法 ${ }^{3)}$}

真空中でポリマーが自由に伸びた状態を見るため，Accelrys Software Inc.製Materials Studioのpolymer builderを用いてポリマー構 造を作成し，分子力場法による構造最適化を行った 4 )，5)，6)。

\section{3) 分子動力学法 ${ }^{7}$}

真空中に存在するポリマーの周囲に圧力をかけ，ポリマーが一定 の密度になる非晶構造を構築した（Materials studioのAmorphous Cell 8）を使用)。次に, COMPASS力場 ${ }^{9}$ ，１０），11），12）にてこの非晶構 造を最適化した後，原子数（N)，温度（T)，体積（V）が一定の条 件（NVTアンサンブル ${ }^{13)}$ ) で100 psec.の間ポリマーに運動を与え, ダイナミクス計算を実施した。このダイナミクス計算により，ポリ マー $0.8 \mathrm{~g}$ が $1 \mathrm{~mL}$ の空間に存在している時の状態を求め, それを視覚 化した。

\section{4.モルタル・コンクリートによるPCの性能試験}

\section{（1）モルタル試験}

セメントにOPC, 砂に豊浦産標準砂を用いた。表4にモルタル調合 を示す。モルタルは，室温下で，セメント，砂をモルタルミキサで 30 秒間空練りした後，PCを含んだ水を加えて 3 分間混練して作製し た。練り上がったモルタルを静置し, 所定時間後に練り返してフロ 一值を測定した。フロー試験は，水平なステンレス板上に置いた内 径 $50 \mathrm{~mm}$ ，高さ $50 \mathrm{~mm}$ の塩化ビニル製中空円筒を用いて行い，モルタ ルをすり切りまで充填し，これを静かに持ち上げて広がったモルタ ルの直交する長径と短径の平均值をフロー值とした。

表 4 モルタル調合

\begin{tabular}{|c|c|c|c|}
\hline W/C (\%) & 水 $(\mathrm{g})$ & OPC $(\mathrm{g})$ & 砂 $(\mathrm{g})$ \\
\hline 30 & 180 & 600 & 600 \\
\hline
\end{tabular}

\section{（2）コンクリート試験}

コンクリートは，温度 $20 \pm 2{ }^{\circ} \mathrm{C}$, 湿度 $60 \pm 5 \%$ の恒温恒湿室で，温 度 $20^{\circ} \mathrm{C}$ に調整した材料（骨材は表乾状態）を用い，容量100Lの強制 練りミキサで練り混ぜた。コンクリートの調合を表5に示す。セメン トは, OPCまたはBeliteを用いた。 
セメント，細骨材を 10 秒間空練りした後，PCを含んだ水を加えて コンクリート調合（1）では30秒，コンクリート調合（2），(3）では モルタルが均一になるまで混練し，少なくとも60秒間混練した。そ して粗骨材を投入後さらに 90 秒間混練して排出し，スランプ，スラ ンプフローと空気量を測定した。その後，バットに静置し，所定時 間ごとに練り返して，スランプ，スランプフローと空気量を測定し た。なお, スランプ, スランプフロー, 空気量は, それぞれJIS A 1101， JIS A 1150, JIS A 1128の方法に準じて測定した。

表 5 コンクリート調合

\begin{tabular}{|c|c|c|c|c|c|c|c|}
\hline \multirow{2}{*}{ 調合 } & \multirow{2}{*}{$\begin{array}{l}\mathrm{W} / \mathrm{C} \\
(\%)\end{array}$} & \multirow{2}{*}{$\begin{array}{c}\text { s/a } \\
(\mathrm{vol} \%)\end{array}$} & \multirow{2}{*}{$\begin{array}{l}\text { セメント } \\
\text { の種類 }\end{array}$} & \multicolumn{4}{|c|}{ 単位量 $\left(\mathrm{kg} / \mathrm{m}^{3}\right)$} \\
\hline & & & & セメント & 水 & 細骨材 ${ }^{\text {a) }}$ & 粗骨材 ${ }^{b)}$ \\
\hline (1) & 51.5 & 49 & $\mathrm{OPC}$ & 320 & 165 & 887 & 955 \\
\hline$(2)$ & 30 & 51 & Belite & 533 & 160 & 867 & 862 \\
\hline (3) & 25 & 40 & $\mathrm{OPC}$ & 660 & 165 & 633 & 982 \\
\hline
\end{tabular}

a)大井川系川砂, b) 青梅産砕石

\section{5. 実験結果と考察}

\section{1 PCの分子量とスランプ保持性能の関係}

図 2 に, モノマー組成比 (PGM-25E/SMAA) が 85/15 で, $M w_{\mathrm{GPC}}$ を 19,000，77,000 と変えた PC-25(85/15)-1，PC-25(85/15)-3 を添加した コンクリートのスランプ保持性能を示す。試験は，減水率 $18 \%$ のコ ンクリート調合（1）で行い，セメントは OPC を用いて，添加量は $0.2 \%$ で行った。図 2 から, PC の分子量が低くなれば，スランプ保 持性能が高くなることがわかる。

図 3 では, モノマー組成比が図 2 と同じ $85 / 15$ で, $M w_{\mathrm{GPC}}$ を 19,000 , 47,000, 77,000 と変えた PC-25(85/15)-1, PC-25(85/15)-2, PC-25 (85/15) -3のセメントへの吸着率を測定した。吸着率の測定は，セメントに OPC を用い, 添加量 $0.15 \%, W / C=1000 \%$ て 表 2 の測定 1 の方法で 行った。図 3 から, 分子量が高いほど吸着率は高く, しかも注水後 $1 \sim 15$ 分で吸着率は大きく立ち上がることがわかる。そして 15 分以 降の吸着速度は緩やかになった。一方，分子量が最も低い PC-25 (85/15)-1 では，注水後 15 分以降も，吸着率は頭を打つことなく継 続的に増大した。図 2 で PC-25(85/15)-1 が高いスランプ保持性能を 示した理由は，このように長い時間にわたって吸着が継続的に続く ためであろうと考えられる。

分子量が低いほど吸着速度が遅くなるのは, PC 1 分子当たりの SMAA 数が少なくなるので (表 1 の NO.4, 5, 6 参照), ポリマー 鎖がセメントに安定して吸着する確率が低くなるためであるうと推 察される。

次に, 吸着速度を遅くするとスランプ保持が上がることの理由を， セメント化学から考察する。セメントは水と接触するとアルミネー 卜相，エーライトで水和反応による急激な発熱が起こり，それらの 発熱は，それぞれ 10〜15 分，または 15 分以内でおさまる ${ }^{14) 。 O P C}$ の発熱速度曲線は図 4 で示され ${ }^{4}$ )，このような初期発熱期（第 1 段階）の後は，反応がほとんど休止してしまう誘導期と呼ばれる期 間があり (第 2 段階)，溶液中のイオン濃度が，結晶核生成に充分な 值になるまで増大寸る。そして, 注水後 $1 \sim 3$ 時間で凝結の始発とな り，そのころ誘導期が終わって，再び活発な水和反応が始まる。そ の後, 反応が加速度的に進行する第 3 段階, 反応が減速する第 4 段 階を経て, 12〜24 時間以後の第 5 段階になると反応が非常に遅くな る。

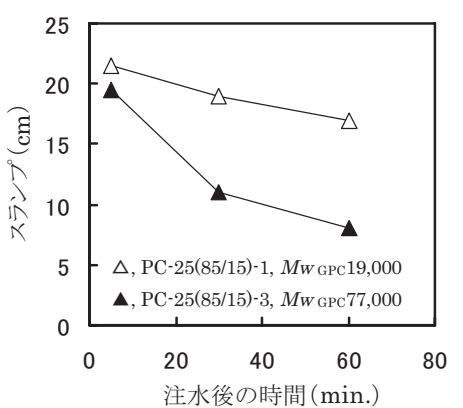

図 $2 \mathrm{PC}$ の分子量とスランプ保持性能 コンクリート調合 (1): セメント, OPC; PC添加量, $0.2 \%$.

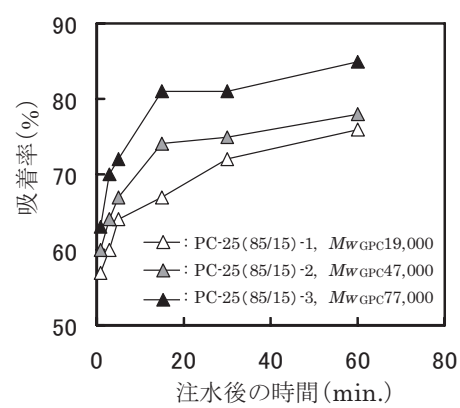

図 3 PCの吸着速度と分子量の関係 (1) 吸着率の測定：(測定 1$), \mathrm{W} / \mathrm{C}=1000 \%$; セメント, OPC; PC添加量, $0.15 \%$

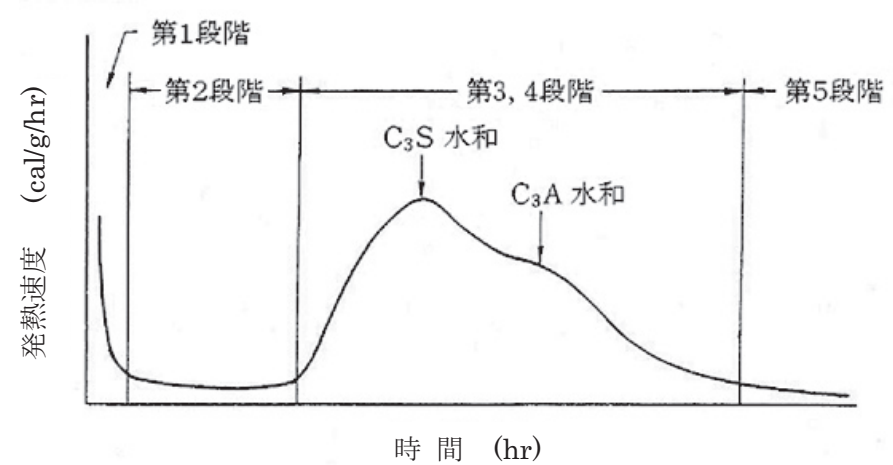

図4 OPC の水和に伴う発熱速度 14 )

第 1 段階と第 2 段階におけるコンクリートは, レディーミクスト コンクリートプラントで製造されて工事現場へ運搬され，打設にい たるまでのコンクリートで，流し込み成形が可能な時期のコンクリ ートである。したがって，この期間のスランプを保持するには，セ メントに吸着した PC (の側鎖) が第 1 段階でのエトリンガイト等の 水和生成物に埋没しないように, 第 1 段階で絶えず新しい PC がセ メントに供給され吸着していることが必要である。

また，著者らは，PCの側鎖原料であるメトキシポリエチレングリ コールが高塩濃度水溶液中で塩析を受けて疎水化することを見出し た ${ }^{15)}$ 。第 1 段階，第 2 段階を通じて，セメントの主要化合物であ る $\mathrm{C}_{3} \mathrm{~S}, \mathrm{C}_{2} \mathrm{~S}, \mathrm{C}_{3} \mathrm{~A}, \mathrm{C}_{4} \mathrm{AF}$ の表面からは主にカルシウムイオン $\left(\mathrm{Ca}^{2+}\right)$ が溶出する。そのため，セメントに吸着した PC は，セメント表面 から現れるこのような非常に高い塩濃度に晒されているので，側鎖 は, 疎水化されて立体反発作用と浸透湿潤作用を次第に無くして行 くものと考えられる。したがってスランプを保持するには，第 2 段 階の期間においても, 新鮮な PC が絶えずセメント表面に供給され ることが必要である。

分子量を下げた PC は, セメントへの吸着速度を遅く制御でき(図 3)，その結果，第 1 段階，第 2 段階のセメントへ継続的に PC が供 給されてスランプ保持性能を発現するのであろうと考えられる。

次に, 図 3 のデータから, セメント $1 \mathrm{~g}$ 当たりに吸着した PC の質 量 $(\mathrm{mg} / \mathrm{g})$ を計算した。その結果を図 5 に示す。PC-25(85/15)-1, PC-25(85/15)-2, PC-25(85/15)-3 の吸着量は, 例えば 60 分後でそれぞ れ, $1.14,1.17,1.28 \mathrm{mg} / \mathrm{g}$ であった。

図 5 のように時間とともに吸着量は増えるので, 次に, PC が最大 
でどのくらいセメントに吸着するのかを, PC の飽和吸着量から調べ た。PCにはPC-10 を用い, 吸着率の測定は, 表 2 の測定 1 の方法 で行い, セメントに OPC を用いて, 添加量は 0.05 から $0.4 \%$ と変え, W/C は $60 \%$ で行った。得られたデータを表 6 , 吸着等温線を図 6 に 示す。図 6 から, PC の飽和吸着量はおよそ $1.5 \mathrm{mg} / \mathrm{g}$ 付近であった。 また, W/C が $60 \%$ から 1000 \%と大きく変わっても, 吸着率は大き な影響を受けなかった。

\section{2 モノマー組成比とスランプ保持性能の関係}

図 7 に, モノマー組成比（PGM-25E/SMAA）を 80/20, 85/15, 87.5/12.5，91/9 と変えた PC-25(80/20), PC-25(85/15)-1, PC-25 (87.5/12.5), PC-25(91/9)を添加したコンクリートのスランプフローの 経時変化を示す。コンクリート試験は, 表 5 の調合（2）で行い，セ メントには Belite を用いた。ここでは, スランプよりもスランプフ ローの方が変化が大きくて分かりやすいので，スランプフローでス ランプ保持性能を評価した。図 7 から, スランプ保持性能は, SMAA 比率が小さくなるにしたがって向上し, PC-25 (87.5/12.5) や PC-25 (91/9)では，混練直後のスランプを 90 分後も維持した。

この時, 混練直後のスランプフロー值を例えば 650〜 750mm に合 わせるのに必要な添加量は, PC-25(80/20), PC-25(85/15)-1 で 0.2\%, PC-25(87.5/12.5)で 0.23\%, PC-25(91/9)で 0.36\%であり, SMAA 比率 が小さいと，多くの添加量が必要であった。

図 8 は, セメントを OPCに変えて, PC-25(80/20), PC-25 (87.5/12.5), PC-25(91/9)のスランプ保持性能を示したものである。コンクリート 試験は表 5 の調合（1）で行った。スランプ保持性能の傾向は図 7 と同様で，SMAA 比率が小さくなるにしたがって向上し，PC- 25 (87.5/12.5), PC-25(91/9)では, 混練直後のスランプを 60 分からそれ 以上の間維持した。

また, 混練直後のスランプを $18 \sim 20 \mathrm{~cm}$ に合わせるのに必要な PC の添加量は, PC-25(80/20), PC-25 (87.5/12.5)で 0.12\%, PC-25(91/9) で $0.2 \%$ ありり, 図 7 と同様, SMAA 比率が小さいと増大した。

以上から, SMAA 比率が小さくなると, スランプ保持性能が向上 すること，一方，所定の初期スランプを得るには添加量が多く必要 になることがわかった。

次に, モノマー組成比が変わることでセメントへの吸着率がどの ように影響を受けるかを調べた。PC には，PC-25(75/25), PC-25 (80/20), PC-25(87.5/12.5), PC-25(91/9)を用いた。吸着率の測定は, 表 2 の測定 2 の方法で行い, セメントに Belite を用い, 添加量 $0.2 \%$, W/C は 200\%で行った。ここでは, 測定の精度を上げるため, GPC にて吸着率を測定した。図 9 に結果を示す。図 9 から, いずれの PC も時間とともに吸着率が上がること, SMAA 比率が大きいほど吸着 率が高いこと, そして SMAA 比率の大きい PC-25(75/25), PC-25 (80/20)の吸着率は注水から 30 分以降では頭を打つのに対し, SMAA 比率の小さい PC-25(87.5/12.5), PC-25(91/9)では, 注水から 30 分後 以降も徐々に吸着率が増大寸る。このように, 吸着速度は, SMAA 比率で制御できることがわかった。

図 10 では, セメントを OPC に変えて, PC-25(80/20), PC-25 (87.5/12.5)，PC-25(91/9)の吸着率を調べた。吸着率の測定は表 2 の測 定 2 の方法で行い, 添加量は図 8 のコンクリート試験の結果と比較 するために PC-25(80/20)，PC-25(87.5/12.5)は 0.12\%，PC-25(91/9)は $0.2 \%$ と $0.12 \%$ で行った。添加量が $0.12 \%$ での SMAA 比率と吸着率の

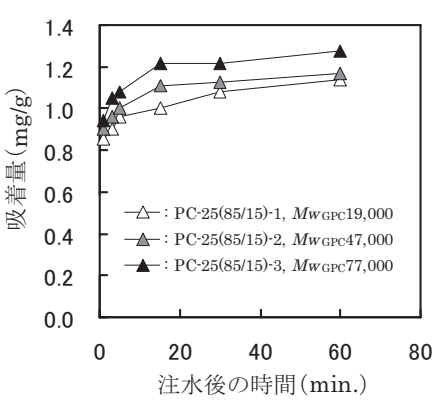

図 $5 \mathrm{PC}$ の吸着速度と分子量の関係 $(2)$ 吸着率の測定: (測定 1$), \mathrm{W} / \mathrm{C}=1000 \%$; セメント, OPC; PC添加量, $0.15 \%$.

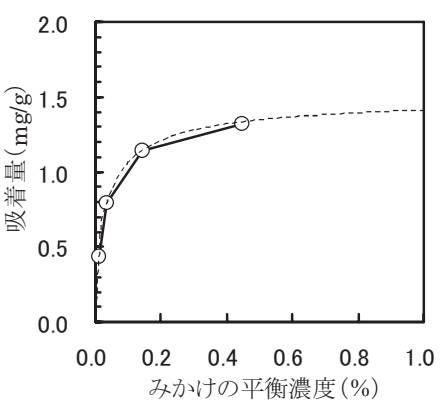

図 $6 \mathrm{PC}-10$ の吸着等温線 吸着率の測定: (測定 1 ), W/C $=60 \%$; セメント, $\mathrm{OPC}$ PC-10添加量: $0.05 \%, 0.1 \%, 0.2 \%, 0.4 \%$

表 $6 \mathrm{PC}$ 飽和吸着量データ $(\mathrm{W} / \mathrm{C}=60)$

\begin{tabular}{|c|c|c|c|c|}
\hline NO. & $\begin{array}{c}\text { 添加量 } \\
(\%)\end{array}$ & $\begin{array}{c}\text { 吸着率 } \\
(\%)\end{array}$ & $\begin{array}{c}\text { 吸着量 } \\
(\mathrm{mg} / \mathrm{g})\end{array}$ & $\begin{array}{c}\text { 水側濃度 } \\
(\%)\end{array}$ \\
\hline 1 & 0.05 & 87 & 0.435 & 0.011 \\
\hline 2 & 0.1 & 79 & 0.790 & 0.035 \\
\hline 3 & 0.2 & 57 & 1.140 & 0.143 \\
\hline 4 & 0.4 & 33 & 1.320 & 0.447 \\
\hline
\end{tabular} セメン:OPC

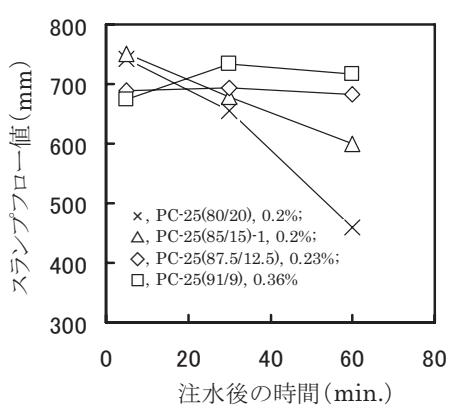

図 7 モノマー組成比とスランプ保持性能 コンクリート調合 (2): セメント, Belite

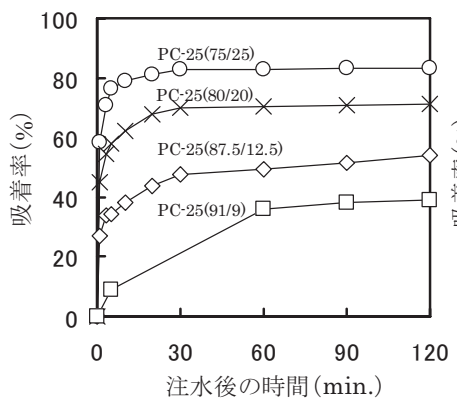

図 9 モノマー組成比と吸着率の経時変化 図10 モノマー組成比と吸着率の経時変化 吸着率の測定：(測定 2$), \mathrm{W} / \mathrm{C}=200 \%$; セメント，吸着率の測定：(測定 2$), \mathrm{W} / \mathrm{C}=100 \%$; セメン, OPC. Belite; PC添加量, $0.2 \%$.

関係は図 9 と同じ傾向であった。すなわち, PC-25(80/20)の吸着率 はやはり 30 分以降で頭打ちになり，PC-25(87.5/12.5)や PC-25 (91/9) のように SMAA 比率が小さいPC では吸着率は低いが継続的に吸着 した。このように, 吸着が継続的に続く PC-25(87.5/12.5), PC-25(91/9) がスランプを長く保持するのは, 図 2, 図 3 で分子量が低い PC-25 (85/15)-1 が，吸着が継続的に続いてスランプを保持したのと同じ現 象であった。

一方で, PC-25(80/20)は, 吸着が添加後 30 分で止まるので, 発熱 速度曲線（図 4）に㧍ける第 2 段階の初期までしかセメント表面に 
供給されない。したがって, 吸着した PC-25(80/20)は, 第 1 段階で 生じる水和生成物に埋没したり, 吸着後に生成する水和層分だけ吸 着厚みが薄くなる。また, セメント表面から溶出寸る高塩濃度に晒 される。これらの理由のため, PC-25(80/20)は分散性能が時間とと もに大きく低下したと推察される（図 7, 図 8)。これに対して PC-25(87.5/12.5), PC-25(91/9)および PC-25(85/15)-1 は, 吸着が継続 的に続くので, 水和生成物ができてもその新しい面に順次吸着して, 分散性能を維持したのであろうと考えられる。

図 11 では, 図 10 の吸着率を $\mathrm{PC}$ の側鎖であるポリエチレングリ コール（PEG）の質量に換算し，縦軸はセメント表面に付いた PEG 量を表す。混練直後 (注水後 5 分) のスランプは図 8 から PC-25(80/20): $19.5 \mathrm{~cm}$, PC-25(87.5/12.5): 20.0cm，PC-25 (91/9): $18.5 \mathrm{~cm}$ でほぼ同等 であった。しかしこの時に吸着した PEG の量には違いがあり, 図 11 から PC-25(80/20): 0.45mg/g, PC-25 (87.5/12.5): 0.29mg/g, PC-25 (91/9): 0.28mg/g（印）であった。PC-25(80/20)では吸着した PEG の量が他の二つの PC に比べると倍近く多いので, スランプはセメ ント表面に付いた PEGの量からは説明できないことが考えられた。 しかし, PC-25(87.5/12.5)と PC-25(91/9)で注水後 5 分に吸着した PEG はほぼ同じ量であったので, PC-25(80/20)は注水後 5 分までの間で スランプに関係しない成分に吸着している可能性も考えられた。

\section{3 吸着速度と減水性能の関係}

図 7 のコンクリート試験では, 用いた PC の種類によって, モル タルが均一に練り上がるまでの時間に違いが見られた。その試験結 果を表 7 に示す。PC-25(91/9)から PC-25(80/20)へと, SMAA 比率が 上がり, したがって吸着速度が速くなるほど, モルタルが均一にな るまでに要する時間は短くなり, 添加量も下がった。

表 7 モノマー組成比を変えたPCの減水性能

\begin{tabular}{|l|c|c|c|}
\hline \multicolumn{1}{|c|}{$\mathrm{PC}$} & $\begin{array}{c}\text { 添加量 } \\
(\%)\end{array}$ & $\begin{array}{c}\text { スランプフロー值 } \\
(\mathrm{mm})\end{array}$ & $\begin{array}{c}\text { モルタルが均一になるま } \\
\text { でに要した時間(秒) }\end{array}$ \\
\hline $\mathrm{PC}-25(80 / 20)$ & 0.20 & 740 & 15 \\
\hline $\mathrm{PC}-25(85 / 15)-1$ & 0.20 & 750 & 30 \\
\hline $\mathrm{PC}-25(87.5 / 12.5)$ & 0.23 & 690 & 40 \\
\hline $\mathrm{PC}-25(91 / 9)$ & 0.36 & 675 & 90 秒以上 \\
\hline
\end{tabular}

コンクリート調合 $(2)$

魚本は, 図 12 に示したような粒子と水が存在する場合, 水の表 面張力等によって粒子どうしが付着し，この付着力は粒子径が小さ いほど大きく粒子径に反比例するので, たとえばセメント粒子どう しが付着しているとき, セメント粒子を引き離すためには粗骨材の 場合の何百倍もの力を必要とすることを示している ${ }^{16)}$ 。そして,

ミキサでの練りまぜは, 粒子-水系がペンジュラーまたはファニキュ ラー状態を経てキャピラリー状態またはスラリー状態となることが 重要で, そのためにはある一定量以上のエネルギーをミキシングに よって与える必要があると指摘している（図 13）16)。

また, 太田らは, 粉体に少量の水を加えたときに粉末状から団子 状となり,さらに水を加えて得られるセメントペーストの流動性が, 水膜厚さと PC 添加量の関数とブリージング水量の関数から推定で きることを示している17)。

そこで, 表 7 でモルタルを混練した時に起こった外観変化の理由 を, 凝集粒子間における水の存在状態に着目して以下のように考察 した。まず, 表 7 で用いたコンクリート調合（2）は水量が少ないの

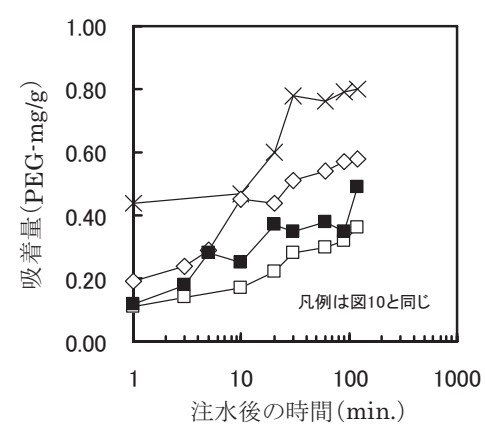

図11 モノマー組成比と吸着量の経時変化 吸着率の測定：(測定 2$), \mathrm{W} / \mathrm{C}=100 \%$; セメン , OPC.

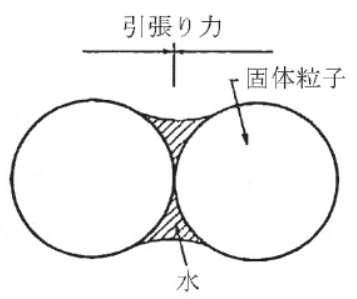

図 12 固体粒子と液体（水）が存在する場合に働く引張 り力 ${ }^{16 \text { ) }}$

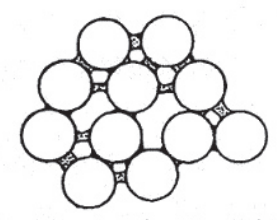

(a) ペンジュラー状態

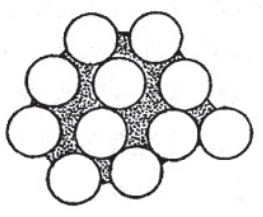

(c) キャピラリー状態

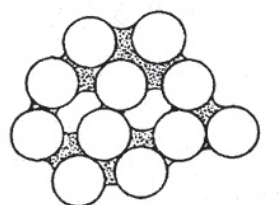

(b) ファニキュラー状態

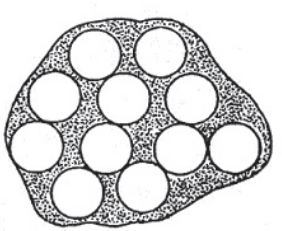

（d）スラリー状態
図 13 粒子間における液体の存在状態 16 )

で，セメントと砂に水を添加したときに，水は凝集したセメント粒 子間に収蔵されてしまって見えなくなる。このときの凝集粒子は, 水で十分に濡れておらず内部に空気を内包している状態 (ペンジュ ラーまたはファニキュラー) である。

ミキサでの混練を続けると凝集粒子は PC の分散作用によって一 部が分散を始め, 収蔵されていた水がセメントペーストとなって表 面に渗夕出る。そして，このセメントペーストが糊となって凝集粒 子どうしをお互いに付着させる。この繰り返しで凝集粒子は, 直径 数 $\mathrm{mm}$ の無数の細かい粒状からそれらが集まった団子状の巨大な塊 に成長し, やがて余剩のセメントペーストがこれらの凝集粒子表面 にとどまり, 表面がしっとりと粘性を帯びるようになる。この間に, 凝集粒子は内部に水を拘束する状態（キャピラリー）に進む。

最後は 1 個のもち状のかたまりに集結し, 収蔵されていた水（セ メントペースト）で覆われるにつれて固さが解れて流動し始める。 その流動性が一定の状態（スラリー）になるまでの時間を目視で測 り, モルタルが均一になるまでに要する時間とした。 
モルタルが均一になるまでに要する時間は，コンクリートを製造 する際の生産性を左右する。特に, W/C の低い高強度コンクリート ほどモルタルが均一になるまでの時間が長くかかるので, 減水剂に はその改善が求められる。本研究では，これまでに述べてきたよう に, PC の化学組成の変化により吸着速度の遅速が可能となるので, 練り上がりまでの時間をコントロールすることが可能となる。した がって，以下ではそれを実験で確認した。

図 14 に PC-25(75/25), PC-25(80/20), PC-25(87.5/12.5)および PC-10 を添加してモルタルを製作する際に, モルタルが均一になるまでに 要した混練時間と得られたモルタルのフロー值との関係を示す。モ ルタルは表 4 の調合で製作し添加量は $0.3 \%$ で行った。側鎖長が 25 モルの一連の PC の中では, SMAA 比率が大きいほどモルタルが均 一になるまでの時間が短くなり, モルタルフロー值も大きくなった。 これは, 図 9, 図 10 で示したように吸着速度が速くなるためと考え られる。一方, SMAA 比率が最も小さい PC-25(91/9)を同じく $0.3 \%$ 添加したモルタルでは, 10 分間混練しても均一なモルタルを得るこ とはできず，セメントペーストが凝集粒子の表面に浮き出て全体を 一体化するまでには到らずバサバサのままであった。

また，PC-10 は，モノマー組成比が PC-25(75/25) と同じ 75/25 であ るにもかかわらず，モルタルが均一になるまでの時間は PC- 25 (75/25)よりも長く，モルタルフロー值も低かった。

表 8 では, PC-10 と PC-25 (75/25)の減水性能をコンクリートでも 比較した。コンクリート試験は，セメントに OPC を用い, $\mathrm{W} / \mathrm{C}=25 \%$ のコンクリート調合（3）で行った。側鎖長が長い PC-25(75/25)の方 が, 図 14 のモルタル試験と同様に高いフロー值が少ない添加量で得 られ，モルタルが均一になるまでの時間も短かった。

PC-10 と PC-25(75/25)の吸着速度は, 図 15 に示したように PC-10 の方が PC-25(75/25)に比べてやや遅いようである。モノマー組成比 が同じであり，分子量も大きいにもかかわらず吸着速度が遅い理由 は後で考察するが，側鎖の長さ以外に吸着速度の遅さも PC-10 の減 水性能を低くしている理由であろうと考えられた。なお, 吸着速度 の測定は表 2 の測定 2 の方法で行い, セメントに OPC を用い, 添加 量 $0.12 \%$,W/C は $100 \%$ で行った。

以上から, SMAA 比率が大きいほど，また，側鎖が長いほど，所 定の流動性を得るのに添加量は少なくて済み，モルタルが均一にな るまでの時間も短くて生産性良くコンクリートを製造できることが わかった。

\section{4 PC の吸着状態のシミュレーション}

前節までで PC の吸着速度とスランプ保持性能, 減水性能との関 連について述べてきた。なお, PC によるセメントの分散効果は基本 的には吸着したポリマーの重なり合いに起因するため, 吸着した PC が実際にセメントペースト中でどのようなコンホメーションを取っ ているのかを知ることは重要である。吸着した PC のコンホメーシ ヨンの視覚化については, これまでに, 太田 ${ }^{18)}$, 19) や山田20) ら によって多くの試みがなされており, PC はセメント上で側鎖が水中 に配向しながら主鎖と側鎖は広がった状態で吸着しているとされて いる。本研究では, PC 水溶液がセメントペーストに添加された時, 実際のコンホメーションにどのような変化があり, どのようにセメ ントに吸着しているのかを探ることを目的とした。

(1) 光散乱法
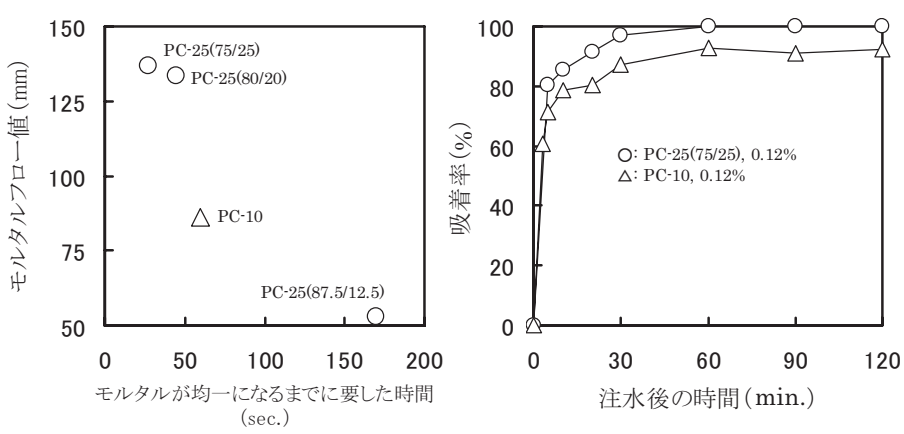

図14 各種PCの減水性能 モルタル調合 (表4): セメント, OPC; $\mathrm{PC}$ 添加量, $0.3 \%$

図15 PC-10とPC-25(75/25)の吸着速度 吸着率の測定：(測定 2 ), W/C $=100 \%$; セメント, OPC;

表 8 側鎖長が異なるPCの減水性能

\begin{tabular}{|l|c|c|c|c|}
\hline \multicolumn{1}{|c|}{$\mathrm{PC}$} & $\begin{array}{c}\text { 側鎖長 } n \\
\text { モル }\end{array}$ & $\begin{array}{c}\text { 添加量 } \\
(\%)\end{array}$ & $\begin{array}{c}\text { フロー值 } \\
(\mathrm{mm})\end{array}$ & $\begin{array}{c}\text { モルタルが均一になるま } \\
\text { でに要した時間(秒) }\end{array}$ \\
\hline $\mathrm{PC}-10$ & 10 & 0.25 & 550 & 140 \\
\hline $\mathrm{PC}-25(75 / 25)$ & 25 & 0.20 & 720 & 50 \\
コンクリート調合 $(3)$
\end{tabular}

まず，光散乱法による $\mathrm{PC}$ の重量平均分子量（ $M w_{\mathrm{LS}} ）$ と固有粘度 から流体力学的半径 $\left(R_{h}\right)$ を測定した。

光散乱法で測定される $M w_{\mathrm{LS}}$ は，ポリマーの絶対重量平均分子量 であり, PC の中和率が変化して溶離液中でポリマーの広がり方が変 化しても影響を受けることはない。

一方，糸まり状のポリマーが溶媒の中を運動する時，系まり内部 の溶媒はポリマーとともに運動するので, 系まり外部の溶媒分子に とっては, ポリマーはあたかも剛体球のように見える。この球の半 径は, 流体力学的半径 $\left(R_{h}\right)$ と呼ばれる 21$)$

一般に, 還元散乱強度 $R(\theta)$ と $M w_{\mathrm{LS}}$ との間には, 次の関係がある 22), 23 )。

$$
\mathrm{K} c / R(\theta)=\left(1 / M w_{\mathrm{LS}}\right)+2 A_{2} c \quad \cdots \cdots
$$

ここで，K は数值因子をまとめた光学定数，c は単位体積中のポ リマーの質量濃度, $A_{2}$ は溶液中のポリマー分子の第 2 ビリアル係数 を表す。本研究で行った GPC 条件下ではポリマー濃度は非常に希薄 なので,（1）式の第 2 ビリアル係数は無視されて次式のように簡略 化できる。

$$
R(\theta)=\mathrm{K} c M w_{\mathrm{LS}}
$$

本研究では, $R(\theta)$ をゼロ散乱角 $\left(\theta=7^{\circ}\right)$ でのレイリー比から測 定し, $M w_{\mathrm{LS}}$ を求めた。

一方, $R_{h}$ はポリマーの固有粘度 ([ $\left.\eta\right]$ ) から次式により求めた ${ }^{23}$ )。

$$
R_{h}=\left[\{3 /(4 \pi)\}\left([\eta] M w_{\mathrm{LS}} / 0.025\right)\right]^{1 / 3} \quad \ldots \ldots
$$

$M w_{\mathrm{LS}}$ と $R_{h}$ の測定結果を表 9 に示す。

表 9 に示す占有面積は, PC の 1 分子が占める面積であり, 次式 (4) から求めた。

$$
\text { 占有面積 }\left(\mathrm{nm}^{2} / \text { 分子 }\right)=\pi R_{h}^{2}
$$

PC の重量平均分子量には, 表 9 では光散乱法によって求めた絶対 


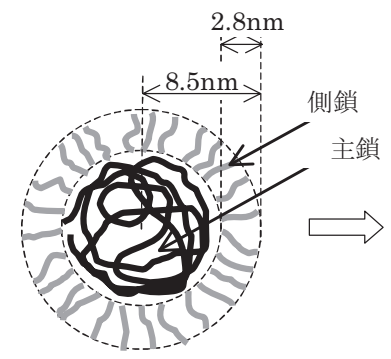

光散乱法の結果

セメントペースト中

図16 PC-10のコンホメーション予想図

重量平均分子量 $\left(M w_{\mathrm{LS}}\right)$ を用い, 表 1 では $\mathrm{GPC}$ から求めた重量平 均分子量 $\left(M w_{\mathrm{GPC}}\right)$ を用いた。両者の值を比較すると, $M w_{\mathrm{LS}}$ は $M w_{\mathrm{GPC}}$ の約 3 倍の大きさであった。これは, $M w_{\mathrm{GPC}}$ が PEG を検量線に用い て計算された換算分子量であることに起因すると考えられる。

田所ら ${ }^{24)}$ によると, EO 付加モル数 $n$ が 7 のポリエチレングリ コールの長さは $1.93 \mathrm{~nm}$ であり,この值をもとに $n$ が 10, 25 の PC-10, PC-25 の側鎖の長さを，末端のメチル基を無視して計算すると，そ れぞれ $2.8 \mathrm{~nm}, 6.9 \mathrm{~nm}$ となる。表 9 では, $n=25$ でモノマー組成比を 変えた NO.2〜 5 のいずれの PC-25 も， $R_{h}$ は 6.4 8.5nm で，ほぼ側 鎖長 $(6.9 \mathrm{~nm})$ に近い值を示している。すなわち, これらの PC-25 は，主鎖を中心にして，その周りを側鎖が拡がって漂っており，か つ主鎖の広がりが小さいコンホメーションを取っている可能性があ る。一方, PC-10 では逆に, 主鎖の広がりが大きいものと推察され る。その模式図を図 16 , 図 17 の左側の “光散乱法の結果”に示す。

ここで,これまでに得られた吸着データと表 9 で得た PC 1 分子当 たりの占有面積とから, $\mathrm{PC}$ のセメント被覆率を求め, $\mathrm{PC}$ がセメン 卜表面で取っているコンホメーションを推察した。吸着データには, OPC で PC-10 の吸着等温線を求めた図 6, ならびに Belite で各種 PC-25 の吸着量を調べた図 9 を用いた。なお，セメント被覆率は次 式（6）から計算した。

セメント被覆率 $(\%)=\left\{\right.$ 吸着量 $\left./\left(1,000 \times M w_{\mathrm{LS}}\right)\right\} \times \mathrm{N}_{\mathrm{A}} \times$ $\left\{\right.$ 占有面積 $/\left(\right.$ 比表面積 $\left.\left.\times 10^{14}\right)\right\} \times 100$

単位は, 吸着量 $\mathrm{mg} / \mathrm{g}$; 占有面積 $\mathrm{nm}^{2} /$ 分子; 比表面積 $\mathrm{cm}^{2} / \mathrm{g}$ であり， $\mathrm{N}_{\mathrm{A}}$ はアボガドロ数を表し $6.02 \times 10^{23}$ である。

結果を表 10 に示す。セメント被覆率は，100\%を大きく超えてセ メント表面を数倍も覆う結果になった。しかし, 吸着率と時間の関係 を表した図 5, 図 9, 図 10, 図 15 からは, 多段吸着が起こっている とは考えらない。したがって、太田らも提案している単分子吸着 ${ }^{19}$ が妥当と考えられる。

表 10 の NO.1 で, PC-10 が OPC に飽和吸着したときのセメント被 覆率は, 吸着量を $1.50 \mathrm{mg} / \mathrm{g}$ と仮定寸れば $593 \%$ あった。そこで, セメント表面を 1 層で覆うには, PC 1 分子当たりの占有面積は表 9 の光散乱法で求めた $227 \mathrm{~nm}^{2}$ の $1 / 5.93$ の $38 \mathrm{~nm}^{2}$ でなければならず, そのときの PC-10の半径は $3.5 \mathrm{~nm}$ と計算される。別途, 光散乱法で 求めた PC-10の $R_{h}$ は 8.5nm なので（表 9), PC-10 はセメント表面で 長さで $41 \%$ ，体積で $7 \%$ まで収縮して吸着していることになる。

また, Belite を用いた各種 PC-25 のセメント被覆率も, 表 10 から

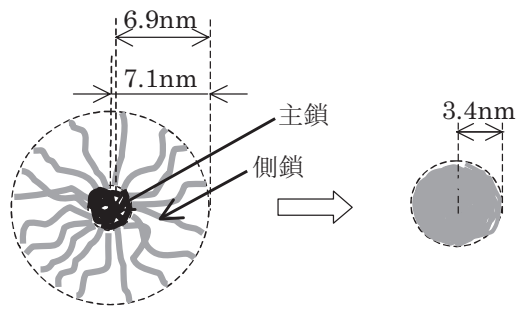

光散乱法の結果

セメントペースト中

図17 PC-25(80/20)のコンホメーション予想図

表 9 光散乱法による $M W_{\mathrm{LS}}$ と $R_{h}$ の測定

\begin{tabular}{|c|l|r|c|c|}
\hline NO. & \multicolumn{1}{|c|}{$\mathrm{PC}$} & $M_{W_{\mathrm{LS}}}$ & $\begin{array}{c}R_{h} \\
(\mathrm{~nm})\end{array}$ & $\begin{array}{c}\text { 占有面積 } \\
\left(\mathrm{nm}^{2} / \text { 分子 }\right)\end{array}$ \\
\hline 1 & PC-10 & 101,300 & 8.5 & 227 \\
\hline 2 & PC-25 (75/25) & 61,100 & 7.4 & 172 \\
\hline 3 & PC-25 (80/20) & 74,100 & 7.1 & 158 \\
\hline 4 & PC-25 (87.5/12.5) & 57,800 & 6.4 & 129 \\
\hline 5 & PC-25 (91/9) & 119,200 & 8.5 & 227 \\
\hline
\end{tabular}

表10 光散乱法によって計算されたPCの吸着状態

\begin{tabular}{|c|c|c|c|c|c|}
\hline \multirow[b]{2}{*}{$\mathrm{NO}$. } & \multirow[b]{2}{*}{$\mathrm{PC}$} & \multicolumn{3}{|c|}{ 吸着実験 } & \multirow{2}{*}{$\begin{array}{c}\text { セメント被覆率 } \\
(\%)\end{array}$} \\
\hline & & $\begin{array}{c}\text { 添加量 } \\
(\%)\end{array}$ & $\begin{array}{c}\text { 吸着率 } \\
(\%)\end{array}$ & $\begin{array}{l}\text { 吸着量 } \\
(\mathrm{mg} / \mathrm{g})\end{array}$ & \\
\hline 1 & PC-10 & - & - & 1.50 & 593 \\
\hline 2 & $\mathrm{PC}-25(75 / 25)$ & \multirow{4}{*}{0.20} & 83 & 1.66 & 668 \\
\hline 3 & PC-25(80/20) & & 71 & 1.42 & 434 \\
\hline 4 & $\mathrm{PC}-25(87.5 / 12.5)$ & & 54 & 1.08 & 344 \\
\hline 5 & PC-25(91/9) & & 39 & 0.78 & 212 \\
\hline
\end{tabular}

セメント:NO.1はOPC, NO.2〜5はBeliteを使用。

668～212\%と高い。図 7 のコンクリート試験でスランプ保持性能を 比較したときの PC-25(80/20)の吸着率は, 表 10 の NO.3 と同じ添加 量（0.2\%）であったので， $71 \%$, 吸着量 $1.42 \mathrm{mg} / \mathrm{g}$, セメント被覆率 434\%であったと推定される。そこで, PC 1 分子当たりの占有面積 は, 表 9 に示した $158 \mathrm{~nm}^{2}$ の 1/4.34の 36nm²でなければセメントを 1 層で覆うことはできず，半径は $3.4 \mathrm{~nm}$ と計算される。PC-25(80/20) の $R_{h}$ は $7.1 \mathrm{~nm}$ なので，これも，上述した $\mathrm{OPC} を$ 用いた $\mathrm{PC}-10$ の吸 着実験と同様に，長さで $48 \%$, 体積で $11 \%$ まで収縮している。

このように PC-10 は OPC の $100 \mathrm{~nm}^{2}$ 当たりに 2.6 個, PC-25(80/20) はBelite の $100 \mathrm{~nm}^{2}$ 当たりに 2.7 個吸着しており, これは太田ら ${ }^{19)}$ がセメントに OPC を用いた時の $\mathrm{PC}\left(M w_{\mathrm{GPC}} 26,000\right)$ の吸着個数が 2.71 個/100nm²であった結果と合う。

以上の考察から予想されるセメントペースト中での PC-10, PC-25(80/20)の模式図を，それぞれ図 16, 図 17 の右側の “セメント ペースト中”に示す。このように PC が大きく収縮しているとすれ ば, PC はセメント上で側鎖と主鎖が一緒になって丸まり，両者でセ メントを分散させている可能性もある。一方で，OPC の場合は，表 面積は接水直後に 2 2.5 倍に増大寸るという報告がある 25$) 。$ その場合には PC は運動するスペースが確保でき，しだいに側鎖が 水中に配向して立体反発作用と浸透湿潤作用を示寸に到ると考えら れる26)。

著者らは前述の文献 15）で，PC の側鎖原料であるメトキシポリ エチレングリコールが高塩濃度水溶液中で塩析を受けて疎水化する こと, そしてその液温が $30^{\circ} \mathrm{C}$ 以上になると会合が始まってあたかも 分子量が増大したように観察されること, 特に鎖長が $n \leqq 10$ のよう 

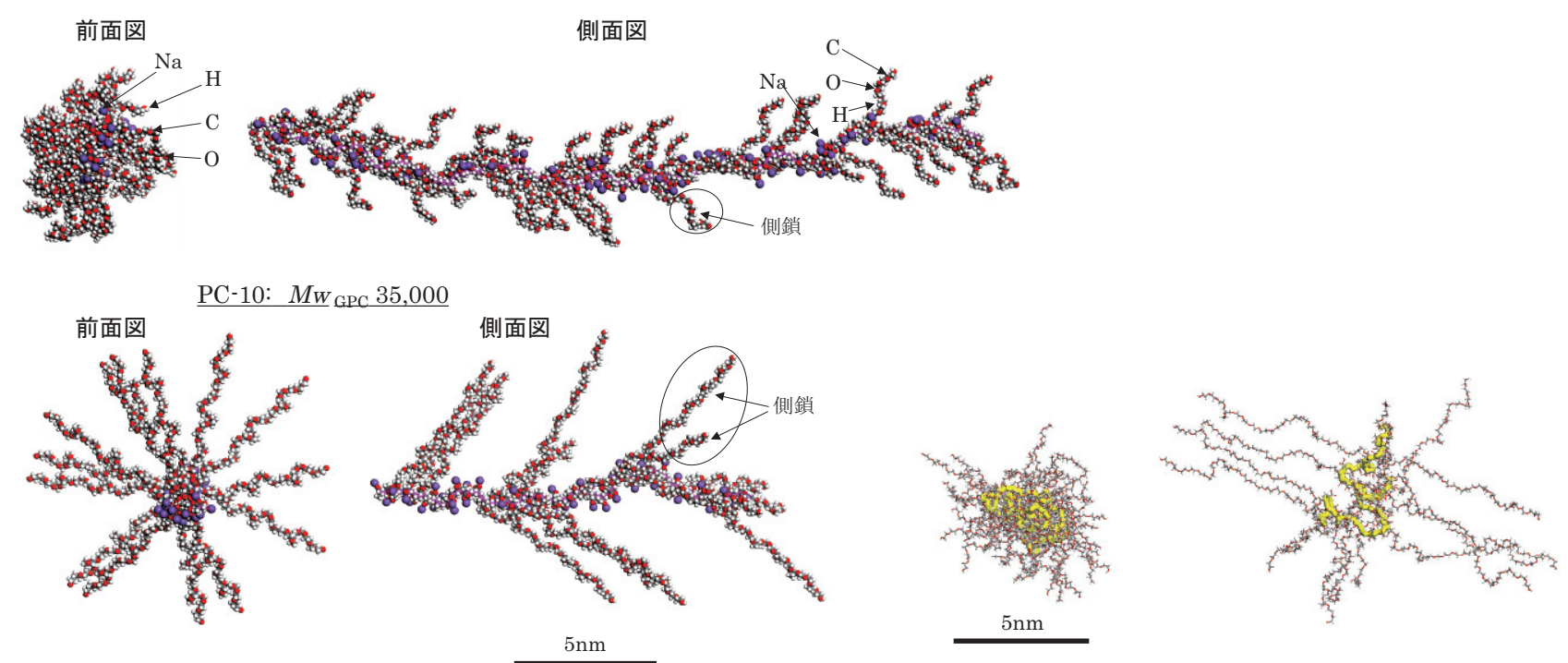

PC-25(75/25): $M_{W}$ GPC 22,000

図18 分子力場法で計算されたPCのコンフォメーション

PC-10: $\quad M_{W}{ }_{\mathrm{GPC}} 35,000 \quad \underline{\mathrm{PC}-25(75 / 25): \quad M_{W} \mathrm{GPC} 22,000}$

図19 分子動力学法で計算されたPCのコンフォメーション

に短いほど疎水化の度合いが大きいことを示した。図 15 で PC-10 が PC-25(75/25)に比べて吸着速度が遅かった理由は, PC-10 の側鎖 同士が疎水化によってより強く会合し, 吸着基であるカルボキシル 基の多くがそれらの内部に包まれるためであろうと推察される。ま た，実際には，そのような PC は複数個集まって，側鎖および主鎖 が絡まり，一つの塊を形成していると考えるのが妥当であるうとも 考えられる。

以上から本研究では, セメントペースト中で PC が大きく縮んで いる可能性のあることが示唆された。これは, 塩の多いセメントペ ースト中での塩析によるものと考えられる。

\section{（2）分子力場法と分子動力学法}

前節において, PC は溶液中では広がっているものの, セメントペ ースト中では塩析によって収縮していると考えられた。本節では, セメントペースト中での PC の広がりについてのこれまでの推察を 検証するために, 真空中での PC のコンホメーションを視覚的に捉 えることを試みた。分子の形態をシミュレートするためには先ず各 $\mathrm{PC}$ の構成原子間に作用寸るファン・デル・ワールス相互作用や静電 作用などに基づくポテンシャルを決定しなければならない。本研究 では分子力場法を用いて各ポテンシャルを決定し，そのポテンシャ ルを用いて分子動力学法により分子に運動を与えたときの形態を求 めた。表 1 に示したモノマー組成比と $M w_{\mathrm{GPC}}$ とから, PC 1 分子当た りの PGM- $n$ E と SMAA の個数を, これらの比重を 1.0 と仮定して計 算し (表 11 に結果を示寸), それらの值をもとに, PCのポリマー構 造をコンピューターを用いて計算した。

分子力場法では静的なポリマーの形態が得られ、本研究では PC 1 分子が自由に伸びた状態が画像化された。図 18 に, 分子力場法で得 た PC-10, PC-25(75/25)のコンホメーションを示す。眓からわかるよ うに, 分子力場法の PC は, 主鎖も側鎖も剛直に伸びきっている。 また，側鎖の長さは, $n$ が 10 モルの PC-10 が $2.8 \mathrm{~nm}$ であり, $n$ が 25 モルの PCでは，PC-25(75/25)が 6.9nm，PC-25(87.5/12.5)が 7.0nm, PC-25(91/9)は $6.8 \mathrm{~nm}$ で, 平均して $6.9 \mathrm{~nm}$ であった。これらの值は, 文献 24）から求めた $n$ が 10,25 のポリエチレングリコールの長さ

表11 PCのポリマー構造を作製するための基礎データ

\begin{tabular}{|c|l|c|c|c|}
\hline \multirow{2}{*}{ NO. } & \multirow{2}{*}{ PCの種類 } & \multirow{2}{*}{$M w_{\mathrm{GPC}}$} & \multicolumn{2}{|c|}{$\mathrm{PC} 1$ 分子あたりの個数 } \\
\cline { 4 - 5 } & & & PGM- $n \mathrm{E}$ & SMAA \\
\hline 1 & $\mathrm{PC}-10$ & 35,000 & 49 & 81 \\
\hline 2 & $\mathrm{PC}-25(75 / 25)$ & 22,000 & 14 & 51 \\
\hline 3 & $\mathrm{PC}-25(87.5 / 12.5)$ & 19,000 & 14 & 22 \\
\hline 4 & $\mathrm{PC}-25(91 / 9)$ & 40,000 & 30 & 33 \\
\hline
\end{tabular}

$2.8 \mathrm{~nm}, 6.9 \mathrm{~nm}$ と一致していた。

一方, PC は, セメントペースト中では図 16, 図 17 に示したよう に, 塩析の効果であたかも周囲から圧力がかかったように圧縮され ていると推察される。そこで, PC が, 周囲から力を受けた時に, ど のようなコンホメーションを取るかを, 分子動力学法で計算した。 本研究では, PC 1 分子が空間に濃度 $0.8 \mathrm{~g} / \mathrm{mL}$ で存在するときの状態 を求めた。一般にポリマーの比重は 1 よりも大きい。PC の構成要素 である PEG やポリアクリル酸の比重もそれぞれ $1.13 \mathrm{~g} / \mathrm{mL}, 1.35 \mathrm{~g} / \mathrm{mL}$ なので, 濃度 $0.8 \mathrm{~g} / \mathrm{mL}$ で PC が空間に広がった状態は, PC が圧縮さ れて完全に固体化するまでの途中段階である。なお, 分子動力学法 では, 主鎖のカルボン酸ナトリウムからすべてのナトリウムを外し, カルボキシル基に変換して計算した。図 19 に, 分子動力学法で得ら れた PC-10, PC-25(75/25)のコンホメーションを示す。図の黄色の線 は主鎖の炭化水素鎖を表し太く誇張してあり, それ以外の線は側鎖 を表す。

分子力場法では PC は円柱状であったのが, 分子動力学法では球 状に縮まっており, コンピューター上でポリマー分子を回転させて も, その様子は変わらなかった。これは, 表 9 の $R_{h}$ から予想された PC のコンホメーション（図 16，17）を裏付ける結果であった。そ して図 19 から明らかなように, PC-25 (75/25)は中心部で主鎖の全体 と側鎖の一部が絡み合ってその周囲を多くの側鎖が漂っているのに 対して, PC-10 では主鎖の全体と側鎖の大部分が中心部で絡み合っ ている。PC-10 の側鎖はセメントペースト中で塩析を受けて疎水化 しお互いに強く会合している15) ので, 図 19 のようにカルボキシル 基はその中に包まれて中心部の電荷密度が低くなっていると推察さ 
れる。また, この結果は, 図 15 での PC-10 と PC-25(75/25)の吸着 速度の違いを, PC-10の主鎖は中心部にあって PEG に内包されてい る（したがって電荷密度が低い）為に吸着が遅いとした推察を説明 するものであった。

一方, 図 18 から図 19 へのダイナミクス計算に要した時間は PC-25(75/25)の方が PC-10 よりも短かった。そこで，この緩和時間 は，逆にセメントペースト中で図 19 のように球状に縮まった PC が セメントに吸着しながら徐々に解けて広がり，セメントを覆うまで の時間と相関するものと考えられた。

寸なわち, 緩和時間が短くて中心部の電荷密度が大きい PC ほど, PC-25(75/25)が PC-10 よりも混練時間が短く添加量が少なくて済ん だように（表 8)，高い減水性能があることを示唆し予測する可能性 がある。

\section{6. まとめ}

本研究で，以下のことが明らかとなった。

（1）PCの Mw が低くなると，また，モノマー組成比の SMAA 比率 が低くなると，スランプ保持性能が向上寸る。これは，PC がセメン 卜に吸着する速度が遅く制御され，その結果，飽和吸着に向かって 長く吸着現象が続くためである。

（2）SMAA 比率が高いと，また，側鎖の PEG の長さが長いと減水 性能が高くなる。すなわち, 少ない添加量で所定のスランプが得ら れ，コンクリート製造時にモルタルが均一になるまでの時間も短く なる。これは, 吸着速度が速く, 注水後に吸着率が急激に上がるた めである。

（3）スランプを長く保持するためには, セメントの発熱速度曲線に 見られる初期発熱期（第 1 段階）と誘導期（第 2 段階）において, PC が継続的に吸着することが必要である。

(4) PC は塩析の作用により流体力学的半径の 4〜5 割まで縮んでセ メントに吸着している。

(5) PC の 1 分子が真空中に濃度 $0.8 \mathrm{~g} / \mathrm{mL}$ で存在するときのコンホ メーションを分子動力学法から求め, それによってセメントペース ト中で PC が受ける塩析の作用を視覚化した。その結果 PC は主鎖を 中心に球状に縮まることがわかり，PC-25(75/25)は中心部に占める カルボキシル基の濃度が高く, PC-10 では多くの側鎖に主鎖が絡ま ってカルボキシル基の濃度が低くなっていることがわかった。また， このダイナミクス計算にかかった時間は PC-25(75/25)の方が短かっ た。この緩和時間と中心部の電荷密度の大きさは, 逆にセメントペ 一スト中で球状に縮まった PC がセメントに吸着しながら徐々に解 けてセメントを覆うまでの時間と相関するものと考えられた。

\section{謝辞}

実験の全般にわたっては，株式会社日本触媒，機能性化学品研究所 第 1 研究グループ湯浅務氏にご協力をいただきました。また，分子 力場法と分子動力学法による PC のコンホメーションを計算するに あたり, 株式会社日本触媒, 基盤技術研究所第 2 研究グループ石田 知史氏から全面的にご協力とご助言をいただきました。ここに深く 感謝の意を表します。

\section{参考文献}

1）大川裕：高性能 $\mathrm{AE}$ 減水剂の特徵・種類および性能，コンクリート工学, Vol.37, No.6, pp. 15-20, 1999. 6

2）河井徹：高性能 $\mathrm{AE}$ 減水剂を用いたコンクリートの適用の現状，コンク リート工学, Vol.37, No. 6, pp. 21-26, 1999. 6.

3）（社）日本化学会: 第 5 版 実験化学講座 12, 丸善, pp. 248-314, 2004.

4) Accelrys Inc.: "Material Studio Data sheet Forcite". Accelrys Inc. (on line), available from

$\langle$ http://accelrys.co.jp/products/accelrys/ms/images/forcite.pdf $\rangle$, (accessed 2008-06-23).

5) Accelrys Inc.: "Material Studio MS-Forcite Plus". Accelrys Inc. (on line), available from

$\langle$ http://accelrys.co.jp/products/accelrys/ms/images/forciteplus.pdf $\rangle$, (accessed 2008-06-23).

6）（社）日本化学会：第 5 版 実験化学講座 12, 丸善, pp. 248-253, 2004.

7）（社）日本化学会：第 5 版 実験化学講座 12, 丸善, pp. 249-250, 2004.

8) Accelrys Inc.: "Material Studio MS-Amorphous Cell". Accelrys Inc. (on line), available from

$\langle$ http://accelrys.co.jp/products/accelrys/ms/images/amorphouscell. pdf $\rangle$, (accessed 2008-06-23).

9) Accelrys Inc.: "Material Studio MS-COMPASS". Accelrys Inc. (on line), available from

〈http://accelrys.co.jp/products/accelrys/ms/images/compass.pdf 〉, (accessed 2008-06-23).

10）（社)日本化学会: 第 5 版 実験化学講座 12 , 丸善, pp. 253, 2004 .

11）（社）日本化学会：第 5 版 実験化学講座 12, 丸善, pp. 336-339, 2004.

12) Michael j. Mcquaid, Huai Sun, David Rigby: Development and Validation of COMPASS Force Field Parameter for Molecules with Aliphatic Azide Chains, J. Comput. Chem., Vol. 25, No. 1, pp. 61-71, 2004.

13）川添良幸，三上益弘，大野かおる：コンピュータ・シミュレーションに 上る物質科学一分子動力学とモンテカルロ法, 共立出版, p. 15, 1997.

14）大門正機編訳：セメントの科学ーポルトランドセメントの製造と硬化一, JME 材料科学, 内田老鶴圃, pp. 47-57, 東京(1989).

15）枚田健, 名和豊春：ポリメタクリル酸一ポリエチレングリコールグラフ トコポリマーを主剤とするコンクリート用高性能 $\mathrm{AE}$ 減水剂，高分子論 文集, Vol. 65, No. 11, pp. 659-669, 2008. 11.

16）魚本健人：コンクリートの練りまぜ技術の現状と問題点，コンクリート 工学, Vol. 26, No. 9, pp. 5-11, 1988.

17）太田顕，名和豊春，大沼博志：セメント粒子の凝集構造とセメントペー ストの流動性の関係，コンクリート工学年次論文集, Vol. 23, No. 2, pp. 271-276, 2001.

18）太田晃，魚本健人：ポリカルボン酸系分散剂の分散作用機構に関する検 討，セメント・コンクリート論文集, No. 52, pp. 138-143, 1998.

19）太田晃，杉山知己，魚本健人：ポリカルボン酸系分散剂の分散作用効果 に関する検討，セメント・コンクリート論文集，No. 53，pp. 122-127， 1999 .

20）山田一夫，高橋智雄，小川彰一，羽原俊祐：硫酸イオン濃度の影響を受 けにくいポリカルボン酸系高性能 $\mathrm{AE}$ 減水剂の分子構造, セメント・コ ンクリート論文集, No. 54, pp. 79-86, 2000.

21）高分子学会，高分子辞典編集委員会：新版高分子辞典，朝倉書店, p. 484, 東京(1988)

22）高分子学会：高分子科学の基礎，東京化学同人, p. 86, 東京(1979).

23) Viscotek: Model 302 TDA Detectors - Instrument Manual 0601 Revision 1.21, Viscotek, pp. 12-21, Texas, USA.

24) H. Tadokoro, Y. Chatani, T. Yoshihara, S. Tahara, S. Murahashi: Structural Studies on Polyethers, [ $\left.\left(\mathrm{CH}_{2}\right)_{\mathrm{m}}-\mathrm{O}-\right]_{\mathrm{n}}$. II . Molecular Structure of Polyethylene Oxide, Makromol. Chem. Vol. 73, pp. 109-127, 1964.

25) 内川浩 他: Influence of $\mathrm{CaSO}_{4} \cdot 2 \mathrm{H}_{2} \mathrm{O}, \mathrm{CaSO}_{4} \cdot 1 / 2 \mathrm{H}_{2} \mathrm{O}, \mathrm{CaSO}_{4}$ on the Initial Hydration of Clinker Having Different Burning Degree，小野 田研究報告, 第 36 巻, 第 2 冊, 第 112 号, pp. 55-67, 1984.

26）名和豊春，一坊寺英夫，大沼博志：ポリエチレンオキシドをグラフト鎖 とするくし形高分子高性能 $\mathrm{AE}$ 減水剂のセメントの分散作用に及ぼす 練混ぜ時間の影響，セメント・コンクリート論文集, No. 56, pp. 64-71, 2002 . 